\title{
The ancestors, violence and democracy in Zimbabwe
}

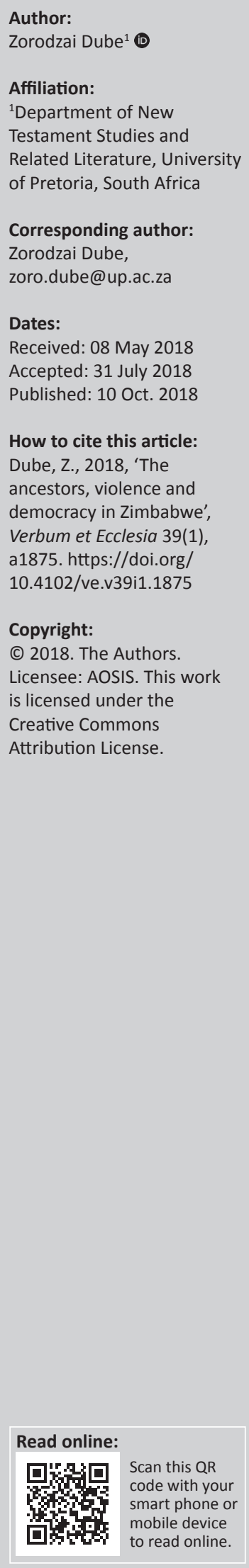

Are the departed silent in their graves or do their voices influence the way we participate in politics? While in other places their voices could be less loud, it is not so in Zimbabwe. Using Terrence Ranger and Eric Hobsbawm's theory regarding invention of traditions, this study explores the deployment of ancestral voices in Zimbabwean politics as a strategy to legitimise political power and social hierarchy. In Zimbabwe, each cycle of election is characterised by constant reminder concerning the voices of the departed, reminding the voters that their democratic exercise through elections must align with the wishes of the nation's ancestors such as Nehanda, Kaguvi, Chamunika and Mwari - the national god. The study consists of three parts: the first part looks into the belief in ancestors, focusing on the ancestral hierarchical order; the second part explores how the spiritual world of the ancestors in terms of its hierarchy is reflected through the spatial arrangement at the village and household levels; and the last section looks into how Mugabe utilises the ideology concerning the ancestors to maintain political power.

Intradisciplinary and/or interdisciplinary implications: Through use of explanatory theories in religious studies and theology, this study unpacks the complexity of theorising politics and democracy within contexts in which the spiritual (in this case, ancestors or gods) takes precedence. After dialoguing and critiquing the current and dominant theories regarding religion across the continent, the article finds Terrence Ranger and Eric Hobsbawm's theory regarding invented traditions the most plausible perspective to explain the interaction of religious canopies and political configurations in Zimbabwe.

\section{Introduction}

In western democracies, in general, politics is regarded as rational, liberal and pragmatic. The citizens are free to choose their leaders based on their policy positions. Equally, public institutions, such as the legislature, judiciary and executive, provide independent mechanisms to ensure that the people's will is protected. If elections are conducted, the results are interpreted as a reflection of people's wishes. Discipline and surveillance are directed to those who are deemed as violating the constitutional rights of the people (Foucault 1979, 1980; Marx \& Engels 2009). ${ }^{1}$ Concerning this, Wilmer (2004), writing from the perspective of Yugoslavia, explains that in a democracy, mechanisms are put in place to ensure collective representation. Here, the basic assumption is that power, whether in the hands of the public or its representatives (parliament), is deployed to govern the people and secure their collective rights. The discursive conviction underlying the above discussion is a certain sense of agency traceable both within the people being governed and in the government that holds and exercises power on behalf of its people.

In this study, however, I take a different approach. What if the state is not a rational being and, instead, its decisions are directed by the ancestors or gods? To explore this question, a case study of Zimbabwe is used. In Zimbabwe, the past, the world of the ancestors, more than the living, is taken to be authoritative and unquestionable. The present and the future cannot deviate from its expected continuity with the past. The living should conduct their affairs based on the dead's dictates and any perceived deviation is perceived as undermining the forebearer's authority. The Zimbabwean people and many African societies share this understanding concerning the dead. In connection to Zimbabwe, the study explores the utilisation of the authoritative voices of the dead for political opportunism. The hypothesis is, because of its sacrality and authoritativeness, the world of the ancestors is vulnerable to manipulation by those in power, serving their own political interest at the expense of the democratic rights of the people to choose their own leaders. Terrence Ranger and Eric Hobsbawm's theory concerning the invention of tradition helps to make meaning of how the ancestral voice provides authoritative traditions that sacralise power and resist change.

1.Here, I am merely using Foucault to illustrate that the government acts as an agent to exercise control and discipline of its subjects. 


\section{Who are the ancestors?}

In Zimbabwe, the ancestors, although physically absent, control everything. The Zimbabwean people believe in God, the creator of good and evil. However, because God is mysterious and distant, people do not directly approach God. Being far and mysterious, God does not really know what people want. As such, people attribute good and bad to God. As such, when misfortunes strike, people say that God is the giver of both good and bad. By being giver of all Mupazvose - God cannot be held accountable concerning matters that happen to human beings, and such are the responsibility of the ancestors.

The ancestors are the solution regarding the problem concerning God's mysterious character. Because the ancestors once lived, they understand human needs and are able to decipher right and wrong on behalf of the living (Gelfand 1970). Before describing the various functions of the ancestors, briefly, we should understand how one becomes an ancestor and life among the ancestors. This background is important to give insight regarding the discourses regarding the understanding of political power in Zimbabwe and how it differs from ideas of power from the perspective of western democracy.

The Zimbabwean people believe that, at death and before one becomes an ancestor, the individual enters into a restless or confusing space. Within this space, the dead person waits for the living to perform a crucial ritual called umbuyiso or kurovaguva ceremony performed 1 year or after the agricultural session from the time of death (Gelfand 1966:56). During the umbuyiso ritual, the dead relative is ritually cleansed (kucheneswa) by pouring a goat, sheep or a cow's blood on the grave. The ritual ensures that a relative who died with moral sins or socially unacceptable practices, such as witchcraft, are ritually cleansed before joining the ancestral world. After performing this ritual, the dead person can now be introduced to his or her final resting place among his or her relatives. While performing the ritual, the name of the diseased is mentioned and depending on seniority, then the ancestors are requested to accord the person his or her rightful place among the dead. Like that of the living, the ancestral world is hierarchically organised based on the ancestors' age during their lifetime. The senior ancestors decide over an issue and give the instruction to the younger ones. This means that family structure and hierarchy while alive continue in the afterlife and the ancestral world is a continuation of the present life albeit in another form (Gelfand 1966:56). Concerning politics and democracy in Zimbabwe, as we shall see, this has implications regarding respect of old age and tradition and hierarchy.

Ancestors fall in three categories - family ancestors, tribal ancestors and national ancestors (Gelfand 1966:56). Family ancestors deal, as while alive, with domestic household matters of protecting, providing and guidance. Tribal ancestors oversee issues concerning the tribe or entire village. Equally, national spirits (mhondoro) are responsible for national matters. Across all categories, ancestors are custodians of custom and people's everyday existence. They must be consulted concerning all matters. Importantly (Gelfand 1970):

on no account (the people) deviate from the path of normality seeking more than he is entitled to lest he lose the protection and beneficial influence of his vadzimu (ancestral spirits). Thus the golden rule is to follow in their footsteps - what was good for them is good for him (p. 1)

Failure to do so would result in sickness as warning from the spiritual world. In such events, a sangoma or n'anga must be consulted, and through the medium, the living asks the ancestors to name their demand for the transgression (Gelfand 1966:59). As we move to the next category, it is important to learn how divinely sanctioned violence is a product of ideas about power and hierarchy.

\section{Ancestors and politics}

Because the study deals with politics, the discussions relate to national spirits (mhondoro) because these are responsible for issues concerning (Gelfand 1970):

succession to the chieftainship, rain drought, epidemic disease, incest and bestiality - indeed any matter which affects the wellbeing of the community as a whole, whilst the vadzimu (family ancestors) are responsible for the protection of the family lineage, small and extended. (p. 1)

National spirits are selected based on how the person, during his or her life time, participated in national politics. For example, the northern tribes - the Zezuru tribes - believe in the territorial ancestors of Nehanda, Kaguvi and Chaminuka. In 1889, Mbuya Nehanda led the first resistance movement against the British Pioneer Column led by Cecil Rhodes. The British Pioneer Column, later known as the British South African Company (BSAC), obtained the exclusive mining rights from the British government to explore the minerals along the Zambezi. In 1890, they settled in Salisbury, now Harare, and instituted a series of legislations which included the Land Apportionment Act that barred Africans from owning land outside the demarcated reserve areas (Shoko 2006). After taking over the land, they named the territory Rhodesia in honour of their leader.

In retaliation, for 2 years, together with her husband, Nehanda led the resistance against the invaders. Nehanda was gifted with spiritual abilities of foretelling the movements of the opponent. Besides politics, she was consulted concerning general national matters. During the war in her possessed state, she could tell where the danger resided and used such spiritual wisdom to guide the war. Legendary stories are told that she could mysteriously disappear before her captors. In addition to being a rainmaker, she could perform healing miracles and advise the locals regarding the advice from the spiritual world. Several books have been written regarding her leadership qualities (Beach 1998; Charumbira 2008; Mutunhu 1976). Some, especially feminist scholars, bemoaned the fact that her contribution as a woman has been downplayed by the fact that she did all this under possession (Mukonyora 1998). 
Her husband - Kaguvi (sometimes the words are attributed to Chamunika) - is remembered for his utterance while being hanged by the British settlers saying, 'my bones shall raise again' - a statement that is now understood within the context of Third Chimurenga or land reform programme as prophetic words towards revenge against current white farmers in the country. Unconfirmed reports suggest that, with others, Nehanda's decapitated head was send to England, where it was displayed as a sign of colonial triumph. ${ }^{2}$

Although she died in 1898, her guiding spirit is frequently consulted by politicians. Nehanda was the spiritual power behind the 1964 second uprising against colonialism. Today, in Zimbabwe, the success of the country's political independence in 1980 is attributed to her, among others. Given this background, Zimbabwe is a country led or directed by the voices of the dead, especially that of Nehanda and Chaminuka. Politics cannot be practised without the wishes of the dead whose decisions take precedence.

Rozvi tribes located in the southern part of the country follow the oracular voices of Mwari that come from the cave at Matonjeni (Daneel 1995; Gelfand 1966:33). While for the Korekore people, God is mysterious, the Rozvi people believe in god who is imminent and residing among the people. Mwari is served by a revered priest (vanyai) who upholds strict moral standards (Cobbing 1977). Daneel describes Mwari as the god of liberation, justice and peace who utters oracles regarding politics, rain, morality and general life of his people. In several instances, Mwari spoke concerning various crucial issues. For example, during the tribal wars between the pastoral Ndebele people who migrated from the South Transvaal in the 1830s and the subsistent Shona people, Mwari spoke and condemned the Ndebele massacre of Shona people (Cobbing 1977). In addition, during the arrival of the British Pioneer Column, Mwari provided oracles regarding the arrival of the so-called 'foreigners'. Today, the term 'Mwari' is used for the Christian God who speaks through the Christian Bible. How does the world view of the ancestor influence politics and partial spaces at the domestic space? How is the belief vulnerable to abuse?

\section{Socio-spatial arrangement based on the spiritual world view}

The hierarchical world view of the ancestors and its concomitant influences will be reviewed beginning at a village level. At the village level, the tribal chief oversees several households and the region. Because the tribal ancestor comes from the lineage of tribal chieftaincy, his or her presence is an embodiment of the tribal spirits (mhondoro). The chief is not an ordinary person; he is a steward on behalf of the ancestors and his sacred installation or appointment is done by the ancestors. If wrong channels of succession of a chief are followed, the ancestors may curse the village by withdrawing rain or allowing pestilence over the village. Similar to national or territorial matters, the ancestors must be consulted concerning all issues without deviation from their instructions. The golden rule is following the footsteps of the ancestors 'what was good for them is good for him' (Gelfand 1970). In each community, the ancestors speak on matters of morality, survival and nature. Regarding morality, the ancestors require community members to adhere to expected cultural moral codes that govern women, men and children. Deviation in the form of murder, stealing, robbery or violence evokes the anger of the tribal ancestors, who punish the village by withdrawing rain, resulting in poor harvest and diseases. If the perpetrators come from a particular family, the ancestors direct their anger towards the family. The tribal chief may also be forced to evict the family from the village.

Importantly, the tribal ancestors are the custodians of the village or tribe. The village elder or chief is merely a steward who governs on behalf of the ancestors. Because the ancestors rule through the chief, it allows possible abuse of power by the village chiefs. In Zimbabwe, knowing the spiritual powers associated with the traditional chiefs, Mugabe bribed them with cars and material goods. In turn, the chiefs were supposed to persuade his or her people to vote for the ruling party.

Led by the father, similar dynamics are noticeable at the household level. The father is a sacred practitioner who bears children on behalf of the ancestors. He has no authority of his own. The ancestors regulate when he can have children and the gender of each child. The extended household members - the aunt, sisters and grandfather - all provide guidance and advice to him and family. In case of a problem, the father should consult the channels of advice. Daily, the father must know that his family is not alone - rather he shares it with the ancestors. As a referee, the father ensures that all family members conduct themselves in a manner that gives the family honour by being exemplary in conduct. The household is hierarchical - the mother and the children are expected to obey and follow the instruction of the father, who represents the ancestors and the elders.

Because the father carries a spiritual mandate, there is a tendency to abuse the role of father. Without checks and balances, the father abuses the wife and children under the guise of implementing ancestral discipline. Beating one's wife is allowed, although many voices are now against this practice. Wife battering is regarded as disciplining the wife on behalf of the ancestors. The father can also beat children as a form of instilling discipline.

\section{The (ab)use of ancestral voices - Case of Zimbabwe}

I argue that the hierarchical world view of the ancestors, mirrored by similar spatial structures at the household level, is politically prone to abuse. There is a tendency among political leaders to abuse tradition to entrench their power. Based on the above, certain areas of abuse of political power can be discussed. 
Elderliness or old age, being regarded as closer to ancestorship, is regarded as a sign of wisdom. As such, countries like Zimbabwe do not see anything wrong in electing a 90 -yearold person - like Mugabe - into power. Ideologically, because of his age, he represents wisdom and proximity to ancestorship. Given that in villages and households elderly people are regarded as custodians of wisdom, the young should not be seen as wanting to lead while the elders are still alive. Even educated people who come from cities should guard the way they speak to elders in the villages, lest their knowledge will be regarded as disrespect. Hierarchy based on age should be respected.

Mugabe manipulated the idea of old age and ancestorship to his advantage. In 2008, Zimbabwe's former president, Robert Mugabe, was losing grip on his political life. After the much contested 2008 national elections, Mugabe woke up to the reality that he had lost both the House of Representatives (parliament) and the presidency - a truth that he, because of slip of tongue and/or old age, only mistakenly confesses. Even before the elections, many factors tilted against Mugabe. He was advanced in age compared to his competitor, the charismatic Morgan Tsvangirai, leader of the opposition party. In addition, Mugabe had been in power since the dawn of independence in 1980. Besides many years in power, he had nothing to show. Because of his poor political and economic decisions, Zimbabwe's economy was deteriorating.

In addition, Mugabe was able to abuse the idea that power is sacred. Unlike in western democracies, he could not be voted out of power. Though losing his grip on the presidency and the House of Representatives (parliament), Mugabe did not resort to building people's confidence by strengthening the economy. He did not consider resigning either. In 2008, the elections were conducted, but for 3 weeks the results were not announced. What was Mugabe doing during that time? During that 'dark period', Mugabe was consulting the ancestors (Ndlovu-Gatsheni 2009). He had lost the elections (Tendi 2013). What puzzled the electorate was the decision by the National Election Commissioner to have Mugabe and the opposition leader Tsvangirai agree over election re-run. Knowing that he had lost the first round, Mugabe was prepared to use all instruments at his disposal to win.

Mugabe later appeared on national television to announce that the national spirit mediums of Mbuya Nehanda and Sekuru Kaguvi have regarded the previous election results as the signal for the return of British colonialism. From that point onwards, the focus shifted from the people's wishes to the voices of the dead.

Furthermore, Mugabe abused the traditional notion that elders are not questioned. Unlike in other western democracies where presidential candidates appear on national television to discuss their party politics, Mugabe scoffed the idea of him discussing policy. Like a village elder whose wisdom should not be questioned, he belittled his opposition's reveries and at public rallies mocked them as children. During each election circle, less policy was discussed. Instead, the national television reminded the people of what the ancestors wanted. For example, though frail and weak in 2013, while seeking another mandate from the people (and also from the ancestors), Mugabe began his campaign by reminding the people that the country belongs to spirits - those who had shed their blood for the liberation of the country. In the process, he scoffed at the opposition leader Tsvangirai for carrying out his political rallies in what used to be Nehanda's village. In his argument, because the country belongs to the fallen heroes, it cannot be simply handed over to any opposition party through election. Doing so would be betraying the wishes of the ancestors (Tendi 2013).

Again, Mugabe abused the traditional notion of ancestors who talk directly through their chosen channel. This aspect is clearer from Mugabe's wife, Grace, who presented herself as a channel of ancestral voices. In 2017, when Mugabe's health was failing him, his wife Grace Mugabe travelled throughout the country reminding the people of the wishes of the dead. On 09 September 2017, while addressing a rally in the eastern part of the country, Grace Mugabe, who had Nehanda's statue outside her office, said she is representing Mbuya Nehanda. ${ }^{3}$ In addition, she claimed to be possessed by the spirit of Nehanda.

Crucially and in honour of the dead, Mugabe instructed the change of street names from colonial names to ancestral names. Across the country, familiar names of national ancestors such as Chamunika, Kaguvi, Chitepo and Tongogara all meant to instil that the natural is permeated by the sacred (Chabata 2012).

\section{(Ab)use of ancestral voices in South African politics}

Practices of democracy and politics predicated on the wishes of the dead are common phenomena in many African countries. For example, in 2011, campaigning for vote ahead of the municipal election in Litchenburg, North-West province, the former president of South Africa, Jacob Zuma, said (News24)

The ancestors will turn their backs against you and you will be bad luck forever if you leave the ANC unhappy. When you vote for a party that is going to lose, then your vote is wasted. That vote does not help South Africa at all. It is the time citizens of a country are asked to make a choice of a party they want in government. Up until 1994 we had no rights to vote.I know what I'm speaking about. When I was recalled from Parliament people were telling me to form another organisation, but I could not because I understand the policies of the ANC. (p. 1)

Despite internal weaknesses, clearly Zuma made his party, the African National Congress (ANC), a sacred organisation; it represented the wishes of the dead. Zuma repeated the same

3.Povo Zim on Twitter: I represent Mibuya Nehanda - Grace Mugabe, https:///twitter com/povozim/status/906746749150224384, accessed 01 May 2018

4.News24, Zuma warns of ancestor revenge, https://www.news24.com/SouthAfrica/ Local-Elections-2011/Ancestors-will-turn-against-deserters-Zuma-20110512, accessed 01 may 2018. 
threat twice in 2016. Firstly, on 28 July 2016 near Brits, north of Pretoria, Zuma threatened that 'the ancestors are turning their backs against you if you leave the ANC and you will have bad luck'. For Zuma, voting was not an act of excising one's right as a citizen. Instead, as he explained, 'opposition parties know they will not win, why should you waste your vote on them' (Shearon 2011). Voting for the opposition is failure to endorse the will of the dead. The following day, on 29 July 2016, while in Soweto, a township in Johannesburg, Zuma reiterated that those who do not vote for the ANC 'will be punished by their ancestors and will have bad luck all their lives'. ${ }^{5}$ Recently, South Africa voted to appropriate land without compensation. During the process, Mosio Lekota - a notable opposition leader and Member of Parliament opposed the move. Though a former inmate together with Nelson Mandela at Robben Island, Lekota is accused of voting against ancestors such as Mandela, Chris Hani and others. Thus, his stance is viewed as provocation towards the ancestors.

\section{Theorising politics and democracy in the context of the gods}

How do we theorise the deployment of ancestral voices over politics? Currently, two main positions which I find less satisfactory are presented. Firstly, the position proposed by Paul Gifford (2015) is summarised in his statement:

Africa's only hope of joining the modern world is to transcend neo-patrimonialism, enforce the rule of law, build institutions, and adopt rational bureaucratic structures, systems, and procedures in education, heath, agriculture, transport and so on. (p. 154)

Gifford's argument that is premised on Berger, Berger and Keller's book Homeless Minds is dismissive of religion. In the book, the authors state that a scientific world view is based on 'measurability, reproducibility, componentiality, interdependence of components, separablility of means and end, implicit abstraction, problem solving inventiveness, emotional management, assumption of maximalization, and multiple relationality' (Berger, Berger \& Kellner et al. 1973). Unlike that of Zimbabwe, such a world view, according to the authors, produces or operates in bureaucratic institutions that are characterised by competence, 'referral, coverage, proper procedure, awareness of redress, anonymity, orderliness, general and autonomous organisability, predictability, general expectancy of justice, and explicit abstraction' (Berger et al. 1973).

Although it makes sense, Gifford's argument is reductive and has an element, though not nuanced, of comparing one world view with another. Africans have been operating within an enchanted world view for centuries and to see their world view as unhelpful within a scientific world view seems that they have to adopt another world view other than their own. In fact, Zimbabweans do not see their belief in ancestral voices as in conflict with a scientific world view.
The second position by Ellis and Ter Haar accommodates and merely describes Africa's religiosity without theorising it. They say that all power, including politics, has spiritual origin; all mundane activities - farming, schooling, sport - 'are ultimately determined in the spiritual world' (Ellis \& Ter Haar 2004). They further argue that:

a religious mode of apprehending reality (even one couched in a spirit idiom) constitutes an epistemology that is simultaneously traditional and modern, capable of updating and renewing itself as times change. (p. 386)

Ellis and Ter Haar's perspective is useful in religious ethos concerning love, humility and hospitality that are perceived as useful organisational culture. For example, in many modern organisations, Buddhist teaching regarding meditation and selflessness are deployed as important interpersonal qualities. Recently, research has been conducted concerning how Buddhist teaching regarding useful emotions is a useful quality for organisational unity (Ekman et al. 2005). Equally, several studies have been conducted and publications have been made regarding the positive aspects embedded in Ubuntu towards good business operation. Most studies from business ethics laud terms such as 'compassion', 'tolerance', 'harmony', 'togetherness' and 'unity'. The common and basic argument is that organisations are driven by people whose emotions and well-being should be taken seriously (Fatoki \& Chiliya 2012; Khomba et al. 2013; Taylor 2014; West 2014). However, in the context of the example regarding Mugabe and Zuma, the ancestors are not evoked to calm or unity but to threaten and exclude. People who do not agree to the ideas of the ruling party - either the Zimbabwe Africa National Union Patriotic Front (ZANU PF) or the ANC - are seen as deviants who deserve misfortunes from the ancestors. Importantly, the narratives about the ancestors are about the past and not about ushering the country into a global and technological world. Based on this, Ellis and Ter Haar's argument falls short of interpreting the political contours within Zimbabwe by not answering the question of why the voices of the ancestors are respected despite people exercising their democratic voting right.

\section{Invented traditions}

How do we explain the deployment of ancestral voices in matters concerning politics? Eric Hobsbawm and Terrence Ranger's interpretive perspective concerning invented traditions provides the interpretive perspective that I found more plausible. I use Ranger and Hobsbawm's perspective to argue that ancestors are allowed to speak on matters of politics and democracy because they are part of invented tradition. For Hobsbawm and Ranger (1983), invented tradition means:

a set of practices, normally governed by overtly or tacitly accepted rules and of a ritual or symbolic nature, which seek to inculcate certain values and norms of behaviour by repetition, which automatically implies continuity with the past. In fact, where possible, they normally attempt to establish continuity with a suitable historic past. (p. 1) 
The past is a repository of community memory drawn into the present to answer particular present needs. Invented traditions differ from customs. Customs are shared practices and beliefs; an important characteristic concerning customs is that they allow for innovation and flexibility. In contrast, invented traditions are characterised by invariance, fixing and repetition (Hobsbawm 1983).

The first important aspect regarding invented traditions is that they appear at a particular point of need in a community's life and are evoked to reduplicate or replicate the past into the present. In the case of Zimbabwe, invented traditions appear at crisis points, a need for meaning. Thus, evocation of invented traditions functions to reinterpret, redirect and realign the present in view of the past. The appearance presupposes a belief within the community that the present is perceived as deviating from the past, thus a need to align the present into the past. Secondly, invented traditions view the past as an oasis, a defining point in a community's history. Events of the past should be reduplicated in the present. Because the past is cherished, each moment of memory is accompanied by high emotions.

Thirdly, rituals in terms of songs and regalia are evoked with great emotion to close the gap between the cherished past and the uncertain present. Rituals replicate or reproduce the emotions associated with the past into the present. In the case of Zimbabwe, opposition leaders are accused of deviating from the past and are targets of violence. They are labelled as traitors and are therefore objects of hatred.

Application of the invented traditions to Zimbabwe reveals important hermeneutical aspects concerning politics and democracy. Several historical events of great importance occurred, but only two memories - namely, Nehanda's lynching and Chaminuka's utterances that his bones shall rise again - are rehearsed. Importantly, since 2000, when Zimbabwe began its chaotic land reform programme, the pictures of Nehanda and Kaguvi became de facto national images. Concerning images, sociologist Stuart Hall comments that pictures are discursive; they feed into particular cultural representation and stereotypes (Hall 1997). Nehanda is portrayed in cultural attire which is meant to portray her as a typical African woman, which creates an aura of innocence around her. On the other hand, her husband - Kaguvi - is portrayed in chains standing next to her. Together with their backs against the brick wall, a gesture signifies colonial cruelty. The pictorial depiction seeks to evoke particular emotions - that an innocent African continent or Zimbabwe was violated and abused by the colonisers. In addition, the pictures serve to convey that, despite the colonial military might, peasants such as Nehanda and Kaguvi drew courage to oppose and fight the colonial power.

Why is the tradition of Nehanda and Kaguvi an important national narrative? Hobsbawm reminds that the moment of 'appearance and establishment' of invented traditions is crucial. Invented traditions are responses to novel situations that take the form of reference to old situations, or which establish their own past by quasi-obligatory repetition by redescribing the influx, ever-changing present as 'unchanging and invariant'.

Concerning Zimbabwe, the year 2008 was the final wake-up call for the ruling party led by Mugabe to realise that people have lost hope and interest in the ruling party. From 1980, Mugabe and his party had run the country based on the ticket that they alone had helped usher the democratic dispensation. Each cycle of election, Mugabe recycles old members of his cabinet, appeasing them because of their liberation war credentials. However, after close to 30 years in power, a new generation emerged; one that did not remember or had a different set of social questions unemployment and demand for institutional accountability by stamping out corruption and nepotism. From the perspective of the Mugabe regime, 2008 was a year of deviation from loyalty and an awakening that the people can vote him out of power.

Plausibly, in my view, the invention of Nehanda's and Kaguvi's memory answers two crucial questions. Firstly, to a new generation that demanded service delivery and accountable governance, the invented tradition of Nehanda and Kaguvi was deployed to divert their attention from bread and butter issues to questions of identity. Fearing losing his legacy as a liberator, the symbol of Nehanda and Kaguvi reminded the masses that Mugabe and his party liberated the country. Implicitly, the message was that rejecting Mugabe is rejecting cherished tradition.

Secondly, the fixation of Nahanda's and Kaguvi's memory was meant to stir hatred towards the minority white population in the country. The false narrative was that the white people who killed Nehanda and Chaminuka are coming back through the opposition party. In addition to the paraded images of Nehanda and Kaguvi, old liberation songs that narrate the cruelty by the white settlers in burning, raping and killing black people were repeated on national television. These were meant to instil a sense of hatred by painting the small white population as the country's enemy. One such song has the following words (Ravengai 2013):

Mbuya Nehanda kufa vachitaura shuwa kuti tinotora sei nyika ino shoko rimwe ravakundiudza tora gidi uzvitonge. Vadzoka kuhondo, shuwa here vakatora anti air kuti ruzhinji ruzvitonge (Mbuya Nehanda upon her death instructed the masses concerning taking back the land. One word she left us is take the gun and let the masses govern themselves). (p. 1)

The effect of such a song when repeatedly sung with the image of Nehanda and Kaguvi stirred hatred towards the white population and diverted attention from blaming Mugabe (Chung 2006; Ndlovu-Gatsheni 2009). As the pain of colonialism was rehearsed and revisited in people's minds, ordinary people took matters in their hands by invading the 
farms belonging to white farmers. Atrocities that included damaging of property, killing and displacement happened. Supporters of opposition parties, most of whom lived on farms, were brutalised and killed. The violence and brutality that ensued at the farms and homes of opposition supporters were construed as vengeance by the ancestors on people who disagree with them. During this process, the statement by Chaminuka uttered on the occasion of his execution saying that his bones shall rise again was interpreted as being fulfilled through violence against the white farmers and 'traitors and sell-outs'. By killing and forcing the white farmers off their land, a myth was created that such heinous acts were retributive justice of the ancestors; they were angry because people voted for the opposition party and indirectly, rejected their instruction. Rituals that cement the hatred of the white farmers and white people in general were revisited through slogans such as (Chitando 2002):

Pasi nevapambe pfumi [down with the Whites resource looter]

Pasi nemhandu [Down with the enemy]

Pasi nevabva kure [down with those who 'come from afar']

Pasi neTsvangirai, Pasi neMDC [Down with Tsvangirai, Down with is party; the Movement for democratic change]. (p. 1-16)

In addition to slogans, rituals in the form of attire were designed. Genuine patriotic Zimbabweans were supposed to carry the ruling party membership card, carry the Zimbabwean flag and be able to recite the ZANU PF slogan (Chitando 2002):
Viva Mugabe [Forward with Mugabe]
Viva musangono we Zanu Pf [Forward with ZANU PF]
Pasi nemhandu [down with enemies] (p. 1-16)

Rituals are meant to maintain continuity with the past. From the slogans, the white people and the opposition party (then) led by Morgen Tsvangirai were regarded as the people's enemies and that of the ancestors. Their presence as traitors is a visible representation or embodiment of an enemy whose presence must be uprooted through violence (LeBas 2006). LeBas poignantly states that the purpose of violence was used as an instrument to further polarise the electorate into opposing camps for the purposes of 'politicizing constituencies, increasing parties' mobilizational capacities, and preventing organizational fragmentation' (LeBas 2006). Violence ensured retention of membership not only by scaring members from leaving, but also by coercing nonmembers to vote for Mugabe. For Terrence Ranger, the invention of ancestral memory is a strategy to create patriotic history; a single narrative whose selective memory is meant to justify a particular way of understanding the past as the only true past, the only correct one. Patriotic history, unlike other forms of historiography, is hegemonic; it silences contesting positions through violence (Ranger 2004).

However, rituals of counter-resistance have emerged that upset the dominant narrative. In churches, the images and stories of David and Jesus who upset the dominant narrative are used as counter-narrative. In addition, Churches teach motivational messages rather than traditional teaching regarding salvation and going to heaven. Because the politicians are seen as not being representatives of the voices of the ancestors, when a politician faces misfortune such as death or sickness, it is interpreted as vengeance from the ancestral world. How the counter-resistant rituals and narratives stand against the main invented traditions is yet to be seen.

\section{Conclusion}

The spirit and structure of modern western democracy is premised upon a liberal, rational, pragmatic and humanistic frame of reference. If transplanted into a traditionalist African context, it lacks its western foundations. Instead, the population tends to interpret democracy in terms of African traditionalism, thus serving the interests of the current leadership. Concerning this, Terrence Ranger's comments regarding abuse of patriotic history poignantly explain the situation in Zimbabwe. As invented tradition in times of crisis, the voice of the ancestors are deployed to connect the past to the present, thereby maintaining consistency. The past, the world of the gods, is sacred and cannot be changed, providing the discourse that perpetuates Mugabe's ruling party. By evoking the past, the ancestors serve to portray the past as innocent yet violated. Equally, like the past, the present is a defining moment of resetting the present to be congruous with the idealised past. In ratcheting fear and anger, the colonial enemy is presented as multiplied through the opposition voices. The images of Nehanda and Kaguvi project not only a narrative of catastrophe but also resilience and resistance. The danger of such patriotic historiography, as Ranger points out, is its selective and parochial memory. It exonerates the current government as victims yet they are perpetrators of injustice. The past is distorted and instead of positive memory, history spew lava or hatred and violence sanctioned by the ancestors. Does the nation have a new repository of traditions that can counter the polarising memory? An answer to this question, so far, is illusive.

\section{Acknowledgements Competing interests}

The author declares that he has no financial or personal relationships that may have inappropriately influenced him in writing this article.

\section{References}

Beach, D.N., 1998, 'An innocent woman, unjustly accused? Charwe, medium of the Nehanda Mhondoro spirit, and the 1896-1897 Central Shona Rising in Zimbabwe', History in Africa 25, 27-54. https://doi.org/10.2307/3172179

Berger, P.L., Berger, B. \& Kellner, H., 1973, The homeless mind: Modernization and consciousness, Random House, New York.

Chabata, E., 2012, 'Feature names and identity in Zimbabwe', Oslo Studies in Language $4(2), 45-59$

Charumbira, R., 2008, 'Nehanda and gender victimhood in the Central Mashonaland 1896-97 rebellions: Revisiting the evidence', History in Africa 35, 103-131. https://doi.org/10.1353/hia.0.0011

Chitando, E., 2002, 'Down with the devil, forward with Christ! A study of the interface between religious and political discourses in Zimbabwe', African Sociological Review/Revue Africaine de Sociologie 6(1), 1-16.

Chung, F., 2006, Re-living the Second Chimurenga: Memories from the liberation struggle in Zimbabwe, Nordic African Institute, Upssala.

Cobbing, J., 1977, 'The absent priesthood: Another look at the Rhodesian risings of 1896-1897', The Journal of African History 18, 61-84. https://doi.org/10.1017/ S0021853700015231 
Daneel, M., 1995, 'Mwari the liberator - Oracular intervention and Zimbabwe's quest for the lost lands', Missionalia: Southern African Journal of Mission Studies 23, 216-244.

Ekman, P., Davidson, R.J., Ricard, M. \& Alan Wallace, B., 2005, 'Buddhist and psychological perspectives on emotions and well-being', Current Directions in Psychological Science 14, 59-63. https://doi.org/10.1111/j.0963-7214.2005.00335.x

Ellis, S. \& Ter Haar, G., 2004, Worlds of power: Religious thought and political practice in Africa, Oxford Press, Oxford.

Fatoki, O. \& Chiliya, W., 2012, 'An investigation into the attitudes toward business ethics and corporate social responsibility by local and immigrant SME owners in South Africa', Journal of Social Sciences 32, 13-21. https://doi.org/10.1080/0971 8923.2012.11893048

Foucault, M., 1979, Discipline \& punish: The birth of the prison, Vintage Books, New York.

Foucault, M., 1980, Power/knowledge: Selected interviews and other writings, 1972-1977, Pantheon, New York.

Gelfand, M., 1966, An African's religion: The spirit of Nyajena; Case history of a Karanga people, Juta, Cape Town.

Gelfand, M., 1970, 'Unhu - The personality of the Shona', Studies in Comparative Religion 4(i), 42, viewed 13 August 2018, from http://www.studiesincomparativereligion. com/public/articles/UNHU\%E2\%80\%94The Personality of the Shona.aspx.

Gifford, P., 2015, Christianity, development and modernity in Africa, Hurst, London.

Hall, S., 1997, Representation: Cultural representations and signifying practices, Sage, London.

Hobsbawm, E.J., 1983, 'Introduction: Inventing traditions', in T.O. Ranger \& E.J. Hobsbawm (eds), The invention of tradition, pp. 1-15, Cambridge Press, Cambridge.

Khomba, J.K., Bakuwa, R.C. \& Kangaude-Ulaya, E.C., 2013, 'Shaping business ethics and corporate governance: An inclusive African Ubuntu philosophy', Global Journal of Management and Business Research 13(5), 30-42.

LeBas, A., 2006, 'Polarization as craft: Party formation and state violence in Zimbabwe', Comparative Politics 38(4), 419-438. https://doi.org/10.2307/20434010
Marx, K. \& Engels, F., 2009, The economic and philosophic manuscripts of 1844 and the Communist manifesto, Prometheus Books, New York.

Mukonyora, I., 1998, 'The dramatization of life and death by Johane Masowe', Zambezia 25, 191-207.

Mutunhu, T., 1976, 'Nehanda of Zimbabwe: A story of a woman liberation fighter', Ufahamu 7, 59-70.

Ndlovu-Gatsheni, S.J., 2009, 'Making sense of Mugabeism in local and global politics: "So Blair, keep your England and let me keep my Zimbabwe"', Third World Quarterly 30, 1139-1158. https://doi.org/10.1080/01436590903037424

Ranger, T., 2004, 'Nationalist historiography, patriotic history and the history of the nation: The struggle over the past in Zimbabwe', Journal of Southern African Studies 30, 215-234. https://doi.org/10.1080/0305707042000215338

Ravengai, S., 2013, 'The political-aesthetic function of song and dance in Zimbabwean theatre 1980-1996', Muziki 10(1), 1-18

Shearon, M., 2011, 'Zuma warns of ancestor revenge', News 24, viewed 01 May 2018 from https://www.news24.com/SouthAfrica/Local-Elections-2011/Ancestors-willturn-against-deserters-Zuma-20110512

Shoko, T., 2006, 'My bones shall rise again': War veterans, spirits and land reform in Zimbabwe, Nordic African Institute, Upssala.

Taylor, D.F., 2014, 'Defining ubuntu for business ethics - A deontological approach' South African Journal of Philosophy/Suid-Afrikaanse Tydskrif vir Wysbegeerte 33, 331-345.

Tendi, B.M., 2013, 'Robert Mugabe's 2013 presidential election campaign', Journal of Southern African Studies 39, 963-970. https://doi.org/10.1080/03057070.2013. 858537

West, A., 2014, 'Ubuntu and business ethics: Problems, perspectives and prospects', Journal of Business Ethics 121, 47-61. https://doi.org/10.1007/s10551-013 1669-3

Wilmer, F., 2004, The social construction of man, the state and war: Identity, conflict, and violence in former Yugoslavia, Routledge, New York. 